\title{
RANCANGAN PERBAIKAN KUALITAS PELAYANAN JASA DENGAN METODE SERVQUAL, IMPORTANCE PERFORMANCE ANALYSIS, DAN QUALITY FUNCTION DEPLOYMENT PADA PLASA TELKOM CABANG DINOYO SURABAYA
}

\author{
Angga Dharmawan \\ Email : anggadharmawan90@yahoo.co.id \\ Febriana Wurjaningrum, SE.,MT \\ Email : febriana71@yahoo.com \\ Departemen Manajemen Fakultas Ekonomi dan Bisnis Universitas Airlangga
}

\begin{abstract}
Measuring the level of customer satisfaction is one of the important factors to overcome the competition is rapidly increased. By knowing the level of customer satisfaction from services provided, the company could undertake the mapping of improved service quality. By using the integration method servqual, IPA, and QFD, the service provider is able to determine the level of customer satisfaction and straightly can make improvements of service with low levels of satisfaction. This research was conducted at Plasa TELKOM Dinoyo Surabaya's branch. From the questionnaires showed that all the attributes of service quality in the questionnaire have a negative gap value. In IPA method showed 6 attributes with high importance and low value the fact. The quality improvement to be done such as improving the application of SOP, increasing the number of officers, officials periodically evaluate, reward the best employees every month, the maximization of information technology systems, and implementing $4 \mathrm{~S}$ culture are really needed.
\end{abstract}

Keyword : Service, Improvement Design, Servqual, Importance Performance Analysis (IPA) and Quality Function Deployment (QFD)

\section{Pendahuluan}

Industri pelayanan jasa merupakan memiliki peran penting dalam dunia bisnis. Bahkan industri manufaktur tidak jarang membutuhkan peranan industri pelayanan jasa untuk mendukung proses bisnisnya. Baik mereka mendirikan divisi pelayanan jasa sendiri maupun menggunakan perusahaan-perusahaan rekanan penyedia layanan jasa lain untuk mendukung berjalannya proses bisnis mereka. Baik buruknya kualitas pelayanan jasa sangat bergantung pada tingkat seberapa jauh pelayanan jasa tersebut dapat memenuhi kebutuhan atau kepuasan pelanggannya. Dengan demikian tidak mudah bagi perusahaan penyedia layanan jasa untuk mengetahui apakah pelayanan jasa yang diberikan pada pelanggan telah memenuhi kepuasan pelanggan atau bahkan sama sekali tidak dapat memuaskan kebutuhan pelanggan.

Plasa TELKOM merupakan salah satu fasilitas yang disediakan oleh PT. Telekomunikasi Indonesia TbK (TELKOM) yang berfungsi sebagai pendukung layanan- 


\section{Angga Dharmawan Febriana Wurjaningrum}

layanan inti yang disediakan oleh TELKOM. Seperti kita ketahui, industri jasa telekomunikasi di Indonesia telah berkembang pesat. Banyak pesaing-pesaing maupun pemain-pemain baru yang bermunculan di industri telekomunikasi Indonesia. Dengan demikian, loyalitas pelanggan TELKOM salah satunya dapat dipengaruhi oleh kinerja Plasa TELKOM dalam memberikan pelayanan pada pelanggan. Semakin baik pelayanan yang diberikan oleh Plasa TELKOM akan berdampak semakin meningkatnya loyalitas pelanggan.

Dalam hal ini, penulis melakukan studi kasus pada Plasa TELKOM Dinoyo Surabaya. Metode yang akan digunakan untuk mendesain kualitas pelayanan Plasa TELKOM adalah integrasi metode servqual, IPA, dan QFD. Keyiga pendekatan tersebut diharapkan mampu memberikan rancangan perbaikan kualitas pelayanan pada Plasa TELKOM Dinoyo Surabaya dengan menganalisa persepsi dan harapan pelanggan, yang kemudian dilakukan analisa setiap customers needs untuk diterjemahkan ke dalam spesifikasi layanan yang tepat.

\section{Landasan Teori}

\subsection{Jasa}

Jasa merupakan suatu hasil yang diciptakan melalui aktivitas dalam keterkaitan antara pemasok dan pelanggan dan melalui aktivitas internal pemasok, untuk memenuhi kebutuhan pelanggan (Gaspersz 1997). Terdapat empat karakteristik jasa yang harus dpertimbangkan dalam memenuhi kebutuhan pelanggan, antara lain intangibility (tidak berwujud), inseparability (tidak dapat dipisahkan dari sumbernya), variability (mudah berubah-ubah), dan perishability (tidak tahan lama) (Kotler 2001).

Dalam melakukan pengukuran kualitas jasa, terdapat dua faktor utama yang harus diperhatikan yaitu, expected service merupakan jasa yang diharapkan oleh pelanggan dan perceived service merupakan jasa yang diterima oleh pelanggan. Di mana suatu layanan jasa akan dianggap baik jika perceived service sesuai atau bahkan lebih baik dibanding dengan expected service dari pelanggan. Sebaliknya jika perceived service tidak memenuhi expected service maka layanan tersebut tidak dapat memberikan kepuasan bagi pelanggan (Parasuraman 1988).

\subsection{Layanan Pelanggan}

Layanan pelanggan merupakan segala kegiatan atau manfaat yang dapat diberikan oleh suatu pihak kepada pihak lain yang pada dasarnya tidak berwujud serta tidak menimbulkan kepemilikan pada suatu produk fisik (Kotler 2002). Layanan pelanggan memiliki dua peran inti bagi perusahaan, yaitu membantu perusahaan mempertahankan pelanggan dan membentuk image perusahaan. Dengan demikian, pelayanan yang diberikan oleh perusahaan dapat berimbas pada loyalitas pelanggan dan terbentuknya 


\section{Jurnal Manajemen Teori dan Terapan \\ Tahun 7. No. 3, Desember 2014}

image pada perusahaan apakah perusahaan tersebut dinilai baik atau buruk oleh pelanggan.

\subsection{Metode Servqual}

Metode servqual merupakan suatu metode pengukuran kualitas yang banyak digunakan dalam penelitian-penelitian tetang kualitas jasa secara luas. Metode ini merupakan pengolahan data kesenjangan (gap) antara persepsi dan harapan pelanggan berdasarkan lima dimensi kualitas jasa yaitu, tangible, reliability, responsiveness, empathy, dan, assurance. Berdasarkan perhitungan gap antara persepsi dan harapan pelanggan berdasarkan kelima dimensi tersebut akan digunakan sebagai acuan perlu atau tidaknya dilakukan perbaikan kualitas pelayanan Plasa TELKOM Dinoyo Surabaya.

Berikut langkah-langkah melakukan analisis gap menggunakan metode servqual pada Plasa TELKOM DInoyo Surabaya:

a. Perhitungan nilai mean pada setiap atribut kuesioner dari masing-masing responden (pengunjung Plasa TELKOM Dinoyo Surabaya) mengenai persepsi pelanggan.

b. Perhitungan nilai mean pada setiap atribut kuesioner dari masing-masing responden (pengunjung Plasa TELKOM Dinoyo Surabaya) mengenai harapan pelanggan.

c. Perhitungan gap nilai mean antara persepsi dan harapan pelanggan.

Dalam melakukan analisis gap terdapat beberapa kriteria yang harus diperhatikan antara lain :

a. Gap negatif, maka layanan Plasa TELKOM Dinoyo Surabaya belum memenuhi harapan pelanggan sehingga perlu dilakukan rancangan perbaikan kualitas.

b. Gap nol, maka layanan yang diberikan Plasa TELKOM Dinoyo Surabaya sudah sesuai dengan harapan pelanggan.

c. Gap positif, maka layanan Plasa TELKOM DInoyo Surabaya telah melebihi harapan pelanggan.

\subsection{Metode Importance Performance Analysis}

Importance Performance Analysis (IPA) merupakan salah satu metode yang dapat menggambarkan tingkat kepuasan pelanggan. Metode analisis ini pertama kali diperkenalkan oleh John A. Martilla dan John C. James pada 1977 yang bertujuan untuk mengukur hubungan antara persepsi konsumen dan prioritas peningkatan kualitas produk/jasa yang kemudian dikenal pula sebagai quadrant analysis. IPA mempunyai fungsi utama untuk menampilkan informasi yang berkaitan dengan faktor-faktor pelayanan yang sangat mempengaruhi kepuasan pelanggan dan loyalitas mereka, dan prioritas faktorfaktor pelayanan yang menurut pelanggan perlu ditingkatkan untuk saat ini.

Grafik IPA dibagi menjadi empat kuadran sebagaimana terlihat pada gambar 1, tiaptiap kuadran tersebut memiliki penjelasan sebagai berikut (Brandt 2000): 


\section{Angga Dharmawan Febriana Wurjaningrum}

a. Kuadran Pertama (high importance \& high performance). Keep up the good work, faktor-faktor pada kuadran ini dianggap sebagai kekuatan perusahaan, dimana konsumen menganggap atribut-atribut pelayanan yang berada pada kuadran ini merupakan faktor penunjang bagi kepuasan pelanggan. Dengan demikian, pihak manajemen berkewajiban mempertahankan kinerja baik yang telah dicapainya.

b. Kuadran Kedua (low importance \& high performance). Possible overkill, faktor-faktor pada kuadran ini memiliki tingkat kepuasan yang tinggi tetapi dianggap tidak terlalu penting bagi pelanggan sehingga pihak manajemen perlu mengalokasikan sumber daya yang terkait dengan faktor-faktor tersebut pada faktor-faktor lain yang mempunyai prioritas perbaikan lebih tinggi misalnya faktor-faktor pada kuadran empat.

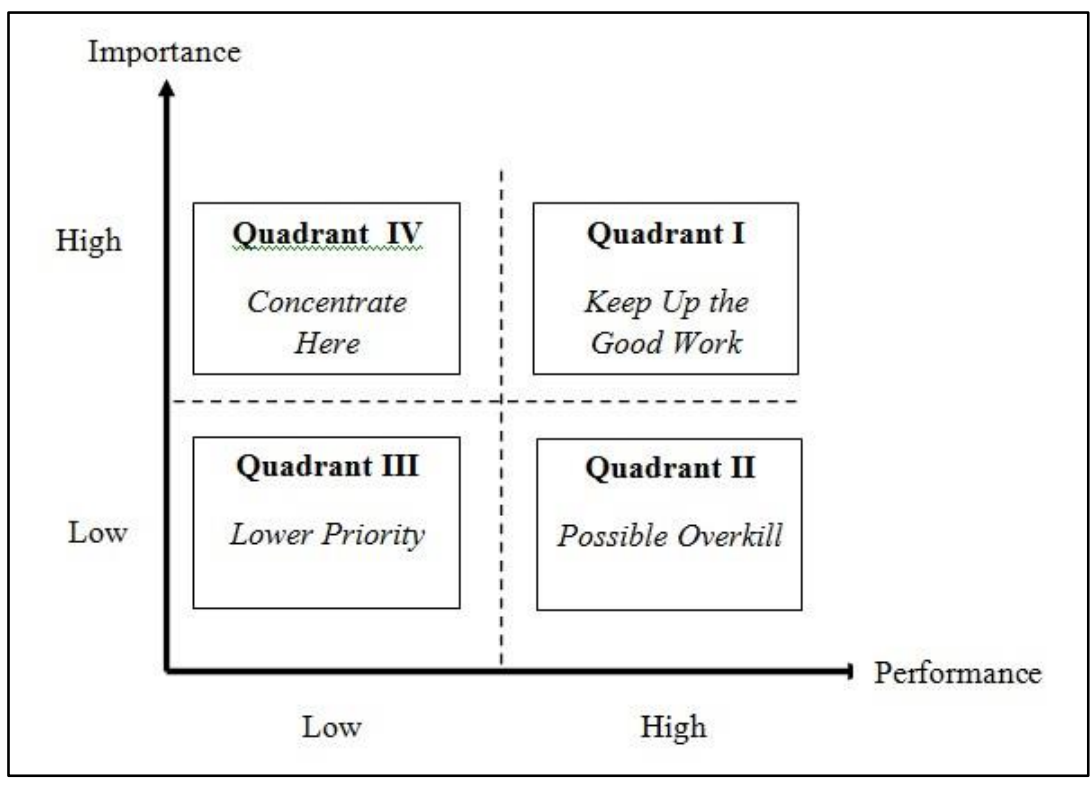

Sumber : Adaptasi dari John A. Martilla and John C. James, "Importance

Performance Analysis", Journal of Marketing, January, 1977

\section{Gambar 1 Grafik Importance Performance Analysis}

c. Kuadran Ketiga (low importance \& low performance). Low priority, faktor-faktor pada kuadran ini memiliki tingkat kepuasan yang rendah tetapi dianggap tidak terlalu penting bagi pelanggan, sehingga pihak manajemen tidak perlu memprioritaskan faktor-faktor pada kuadran ini untuk dilakukan perbaikan.

d. Kuadran Keempat (high importance \& low performance). Concentrate here, faktorfaktor pada kuadran ini sangat dianggap penting oleh pelanggan tetapi kondisi pada saat ini belum memuaskan sihingga pihak manajemen berkewajiban memprioritaskan peningkatan pada faktor-faktor dalam kuadran ini.

Metode menampilkan data IPA ada dua macam (Martinez 2003), yaitu sebagai berikut: 


\section{Jurnal Manajemen Teori dan Terapan \\ Tahun 7. No. 3, Desember 2014}

a. Menempatkan garis perpotongan kuadran pada nilai rata-rata pada sumbu tingkat kepuasan dan sumbu prioritas penanganan dengan tujuan mengetahui secara umum penyebaran data terletak pada kuadran keberapa.

b. Menempatkan garis perpotongan kuadran pada nilai rata-rata hasil pengamatan pada sumbu tingkat kepuasan dan sumbu prioritas penanganan dengan tujuan untuk mengetahui secara spesifik masing-masing faktor terletak pada kuadran berapa.

\subsection{Metode Quality Function Deployment}

Secara umum, Quality Function Deployment (QFD) merupakan suatu metode yang digunakan untuk memusatkan perhatian pada hal-hal yang menjadi kebutuhan atau keinginan pelanggan dalam upaya penyusunan standar layanan. Gaspersz (1997) menyatakan bahwa QFD merupakan suatu proses atau mekanisme untuk menentukan kebutuhan pelanggan dan menterjemahkan kebutuhan-kebutuhan itu kedalam kebutuhan teknis yang relevan, di mana masing-masing area fungsional dan tingkat organisasi dapat mengerti dan bertindak.

House of Quality (HOQ) merupakan bentuk dari interpretasi QFD, dimana matriks ini terdiri dari dua bagian utama yaitu bagian horizontal dari matriks yang berisi informasiinformasi berhubungan dengan pelanggan, dan bagian vertikal yaitu matriks yang berisi informasi teknis sebagai respon bagi input pelanggan.

$H O Q$ merupakan suatu proses pemahaman dari tingkat kepentingan, ekspektasi, dan persepsi pelanggan yang dirangkum dalam suatu matriks. (Gaspersz 1997). Pada matriks ini terdapat beberapa bagian yang setiap bagian berisi informasi yang berkaitan antar satu dengan lainnya. Bentuk umum matriks $H O Q$ terdiri dari enam komponen utama seperti pada gambar , antara lain yaitu: (Gasperz 1997)

1. Voice of Customer (VOC), daftar persyaratan terstruktur yang berasal dari persyaratan pelanggan. Bagian ini bisa didapat dengan penyebaran kuesioner kepada pelanggan dengan metode SERVQUAL.

2. Technical Response, daftar respon pihak manajemen yang relevan menanggapi hasil voice of customer. Bagian ini dibuat oleh pihak manajemen mengenai respon-respon apa yang memungkinkan untuk diterapkan dalam merespon kebutuhan pelanggan.

3. Relationship Matrix, matrik ini menggambarkan persepsi tim QFD mengenai keterkaitan antara VOC dan Technical Response. Skala yang biasa digunakan dalam matriks ini digambarkan dengan symbol-simbol berikut:

- = melambangkan hubungan kuat

$\mathrm{O}=$ melambangkan hubungan sedang

$\Delta=$ melambangkan hubungan lemah 


\section{Angga Dharmawan Febriana Wurjaningrum}

4. Planning Matrix, matriks ini menggambarkan persepsi pelanggan yang diamati dari hasil VOC. Di mana didalamnya berisi Importance to Customer, Customer Satisfaction Performance, Expected Satisfaction Performance, Improvement Ratio, Raw Weght, dan Normalized Raw Weight.

5. Technical Corelation, digunakan untuk mengidentifikasi hubungan antara masingmasing Technical Response apakah saling mendukung atau saling mengganggu satu sama lain.

6. Technical Matrix, bagian ini berisi target-target yang harus dicapai untuk setiap Technical Response. Penargetan ini dilakukan oleh pihak manajemen yang lebih memahami kapasitas perusahaan dalam pencapian target.

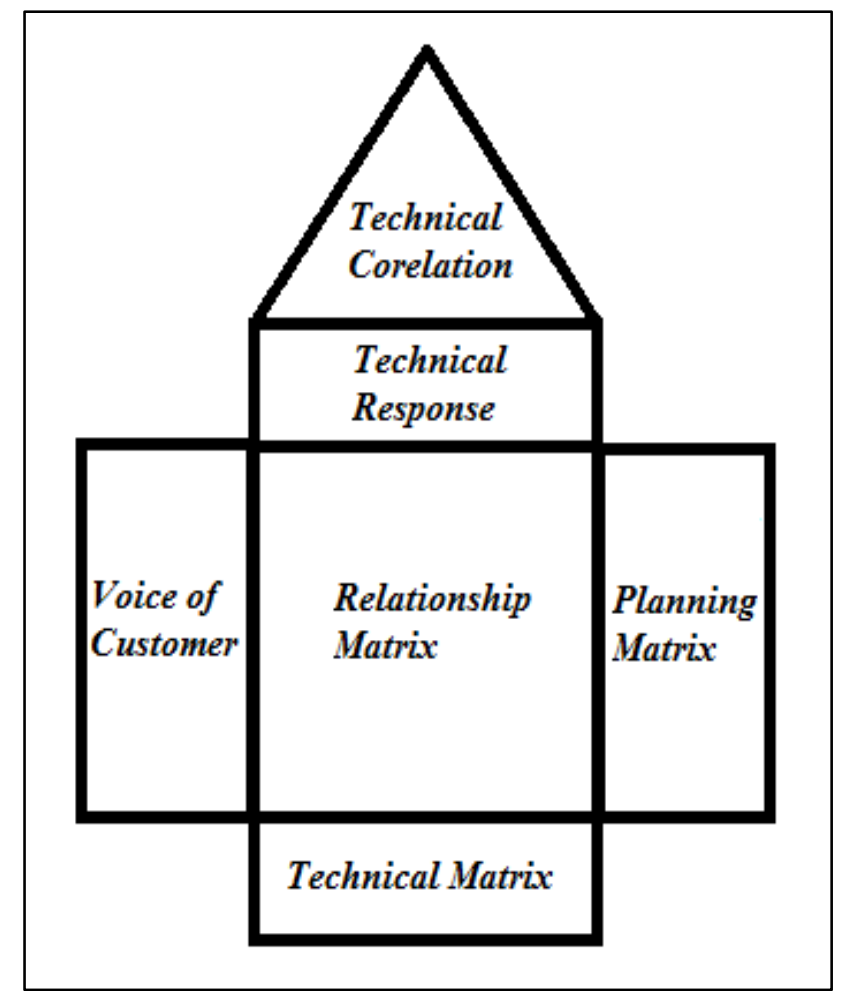

Sumber : Vincent Gasperz, (1997), Konsep Vincent : Penerapan Konsep Vincent tentang Kualitas dalam Manajemen Bisnis Total, Gramedia Pustaka Utama, Jakarta

\section{Gambar 2 The House of Quality}

\section{Metode Penelitian}

\subsection{Pengumpulan Data}

Penelitian ini menggunakan metode kuantitatif di mana penentuan sample menggunakan metode purposive sampling dan accidental sampling. Dalam Penelitian ini prosedur pengumpulan data yang digunakan antara lain :

a. Survey Pendahuluan

Prosedur ini dilakukan untuk mengetahui kondisi serta permasalahan yang terjadi pada perusahaan, serta menggali informasi-informasi yang diperlukan untuk menjawab 


\section{Jurnal Manajemen Teori dan Terapan \\ Tahun 7. No. 3, Desember 2014}

rumusan masalah yang telah dirumuskan, terutama mengenai kualitas pelayanan jasa yang disediakan oleh perusahaan.

b. Studi Kepustakaan

Tahap ini dilakukan dengan cara pengumpulan data dari literatur sebagai Iandasan teori dari penelitian. Hal ini dilakukan untuk membentuk kerangka berpikir yang sistematis dalam penyelesaian masalah dalam penelitian.

c. Studi Lapangan

Prosedur ini dilakukan untuk pengumpulan data primer yang secara langsung diperoleh dari perusahaan untuk tujuan penelitian. Prosedur ini dilakukan dengan cara kunjungan langsung ke objek penelitian. Teknik yang dilakukan dalam studi lapangan antara lain wawancara, observasi, dan dokumentasi.

d. Kuesioner

Penyebaran kuesioner dilakukan pada 100 responden yaitu pengunjung Plasa TELKOM yang pernah merasakan pelayanan Plasa TELKOM cabang Dinoyo Surabaya Sekurang-kurangnya dua kali dalam enam bulan terakhir.

\subsection{Definisi Operasional Variabel}

Definisi operasional bertujuan untuk menyatukan pengertian agar terjadi perbedaan pandangan atau kesalahpahaman dalam mendefinisikan variabel-variabel yang akan dianalisis. Berikut definisi operasional variabel yang akan digunakan menurut Parasuraman et.al (1990), sebagai berikut:

a. Tangibles, atau bukti fisik yaitu merupakan fasilitas yang dapat dilihat dan digunakan oleh perusahaan sebagai media dalam memenuhi kebutuhan pelanggan.

b. Reliability, atau keandalan yaitu kemampuan perusahaan untuk memberikan pelayanan sesuai yang dijanjikan secara akurat dan terpercaya.

c. Responsiveness, atau ketanggapan yaitu suatu kemauan untuk membantu dan memberikan pelayanan yang cepat dan tepat kepada pelanggan.

d. Assurance, atau jaminan dan kepastian yaitu pengetahuan, kesopansantunan, dan kemampuan para petugas Plasa TELKOM untuk menumbuhkan rasa percaya pelanggan pada perusahaan.

e. Empathy, yaitu memberikan perhatian tulus dan bersifat individual pada para pelanggan.

\subsection{Metode Analisis Data}

Proses analisis data dalam penelitian kuantitatif pada umumnya dilakukan sepanjang alur penelitian. Dimana analisis data dilakukan secara terus-menerus mulai awal penelitian hingga akhir penelitian. Teknik analisis data pada penelitian ini adalah sebagai berikut: 


\section{Angga Dharmawan \\ Febriana Wurjaningrum}

1. Tahap penelitian awal, dalam tahapan ini dilakukan penjelasan rumusan masalah dan tujuan penelitian.

2. Tahap pengumpulan data, dalam tahap ini peneliti melakukan pengumpulan datadata yang akan dibutuhkan dalam penelitian. Tahapan ini dilakukan dengan cara studi kepustakaan, survey lapangan, in depth interview pada pihak-pihak yang terkait pada objek penelitian, observasi objek, dan sebagainya.

3. Tahap penentuan atribut-atribut kepuasan pelanggan, pada tahapan ini peneliti membuat beberapa atribut yang digunakan untuk mengukur tingkat kepuasan pelanggan terhadap kualitas pelayanan jasa yang disediaan perusahaan.

4. Tahap pembuatan dan penyebaran kuesioner, dalam tahapan ini peneliti membuat kuesioner berdasarkan atribut-atribut kepuasan pelanggan yang telah dibuat pada tahap sebelumnya.

5. Tahap analisis gap persepsi dan ekspektasi pelanggan, dalam tahap ini hasil survey diolah menggunakan metode SERVQUAL untuk mendapatkan gap antara persepsi dan harapan pelanggan terhadap kualitas pelayanan yang disediakan perusahaan.

6. Tahap analisis prioritas atribut-atribut kualitas pelayanan, dalam tahap ini dilakukan analisis pada atribut-atribut kualitas pelayanan untuk mendapatkan prioritas atribut pelayanan yang harus segera diperbaiki dengan menggunakan metode Importance Performance Analysis (IPA).

7. Tahap penyusunan Quality Function Deployment (QFD), dalam tahap ini peneliti menyusun QFD dengan menggunakan matriks House of Quality (HOQ) berdasarkan hasil dari tahap sebelumnya.

8. Tahap analisis hasil QFD, pada tahap ini peneliti melakukan pembahasan terhadap hasil QFD yang telah disusun serta mengidentifikasi apakah hasil tersebut dapat diterapkan.

9. Tahap kesimpulan dan saran, tahap ini memaparkan kesimpulan yang dapat diambil dari hasil penelitian untuk dapat memberikan saran yang dapat dimanfaatkan oleh perusahaan.

\section{Hasil dan Pembahasan}

\subsection{Penyusunan Kuesioner}

Hasil rancangan kuesioner penelitian ke dalam lima dimensi sevqual, dapat dilihat pada tabel 1 berikut : 


\section{Jurnal Manajemen Teori dan Terapan Tahun 7. No. 3, Desember 2014}

Tabel 1 Kuesioner Penelitian dalam Lima Dimensi Servqual

\begin{tabular}{|c|c|c|}
\hline Dimensi Kualitas & & Atribut-Atribut Kualitas \\
\hline \multirow{7}{*}{ Tangible } & 1. & Ketersediaan fasilitas parkir yang memadai. \\
\hline & 2. & $\begin{array}{l}\text { Kelengkapan fasilitas pendukung ruang tunggu. (tempat } \\
\text { sampah, mesin antrian, tempat brosur, kotak saran, dll) }\end{array}$ \\
\hline & 3. & Kenyamanan ruang tunggu. \\
\hline & 4. & Kebersihan toilet di area ruang tunggu. \\
\hline & 5. & Kerapian penampilan petugas customer service. \\
\hline & 6. & Jumlah counter pelayanan memadai. \\
\hline & 7. & Kenyamanan counter pelayanan. \\
\hline \multirow{3}{*}{ Assurance } & 1. & Keyakinan pelanggan terhadap kemampuan petugas. \\
\hline & 2. & Keyakinan pelanggan pada solusi yang diberikan petugas. \\
\hline & 3. & Keamanan area ruang tunggu. \\
\hline \multirow{9}{*}{ Reliability } & 1. & Keterampilan pegawai dalam memberikan solusi. \\
\hline & 2. & $\begin{array}{l}\text { Keterampilan pegawai dalam berkomunikasi dengan } \\
\text { pelanggan. }\end{array}$ \\
\hline & 3. & $\begin{array}{l}\text { Ketersediaan petugas tambahan pada saat terjadi antrian } \\
\text { yang panjang. }\end{array}$ \\
\hline & 4. & Kesiapan petugas dalam melayani pelanggan \\
\hline & 5. & $\begin{array}{l}\text { Kesiapan petugas tambahan pada saat terjadi antrian yang } \\
\text { sangat panjang. }\end{array}$ \\
\hline & 6. & Kesiapan petugas merespon keluhan pelanggan. \\
\hline & 7. & $\begin{array}{l}\text { Keakuratan pencatatan atau dokumentasi keluhan } \\
\text { pelanggan. }\end{array}$ \\
\hline & 8. & Keakuratan informasi yang diberikan oleh petugas. \\
\hline & 9. & Pengetahuan petugas tentang produk-produk perusahaan. \\
\hline \multirow{3}{*}{ Responsiveness } & 1. & Kecepatan petugas dalam melayani pelanggan. \\
\hline & 2. & $\begin{array}{l}\text { Kecepatan petugas dalam memberian solusi pada keluhan } \\
\text { pelanggan. }\end{array}$ \\
\hline & 3. & $\begin{array}{l}\text { Kesediaan petugas membantu pelanggan menanggapi } \\
\text { keluhan. }\end{array}$ \\
\hline \multirow{4}{*}{ Empathy } & 1. & $\begin{array}{l}\text { Kesediaan petugas mengucapkan salam sebelum dan } \\
\text { sesudah melayani pelanggan. }\end{array}$ \\
\hline & 2. & Kesopanan petugas terhadap pelanggan. \\
\hline & 3. & Keramahan petugas dalam melayani pelanggan. \\
\hline & 4. & Perhatian petugas terhadap keluhan yang disampaikan. \\
\hline
\end{tabular}

\subsection{Analisis Servqual}

Setelah penyebaran kuesioner dilakukan analisis servqual di mana hasil perhitungan gap performance dapat dilihat pada tabel 2 berikut: 
Tabel 2 Gap Performance

\begin{tabular}{|c|c|c|}
\hline Dimensi Kualitas & Pernyataan & Gap Performance \\
\hline \multirow{7}{*}{ Tangible } & 1. & $-0,84$ \\
\hline & 2. & $-0,71$ \\
\hline & 3. & $-0,81$ \\
\hline & 4. & $-0,86$ \\
\hline & 5. & $-0,70$ \\
\hline & 6. & $-1,07$ \\
\hline & 7. & $-0,84$ \\
\hline \multirow{3}{*}{ Assurance } & 1. & $-0,77$ \\
\hline & 2. & $-0,82$ \\
\hline & 3. & $-1,01$ \\
\hline \multirow{9}{*}{ Reliability } & 1. & $-0,78$ \\
\hline & 2. & $-0,75$ \\
\hline & 3. & $-1,15$ \\
\hline & 4. & $-0,98$ \\
\hline & 5. & $-1,07$ \\
\hline & 6. & $-0,92$ \\
\hline & 7. & $-0,79$ \\
\hline & 8. & $-0,66$ \\
\hline & 9. & $-0,66$ \\
\hline \multirow{3}{*}{ Responsiveness } & 1. & $-0,81$ \\
\hline & 2. & $-0,82$ \\
\hline & 3. & $-0,87$ \\
\hline \multirow{4}{*}{ Empathy } & 1. & $-0,80$ \\
\hline & 2. & $-0,76$ \\
\hline & 3. & $-0,73$ \\
\hline & 4. & $-1,06$ \\
\hline
\end{tabular}

Sumber : Pengolahan Data

Pada tabel 2 diatas dapat dilihat bahwa seluruh atribut pelayanan bernilai gap negatif, hal ini berarti bahwa persepsi pelanggan terhadap kualitas layanan Plasa TELKOM Dinoyo Surabaya masih dibawah harapan mereka. Dengan demikian masih diperlukan rancangan perbaikan perbaikan kualitas layanan. Hasil dari analisis ini kemudian akan dijadikan input data dalam metode IPA dengan melihat nilai kepentingan masing-masing atribut untuk mengetahui atribut mana saja yang diprioritaskan untuk dilakukan rancangan perbaikannya.

\subsection{Importance Performance Analysis (IPA)}

Metode ini berfungsi untuk mengetahui prioritas utama atribut yang harus dlakukan perbaikan, di mana hasil dari metode analisis ini diinterpretasikan ke dalam kuadran empat dimensi sebagai berikut: 


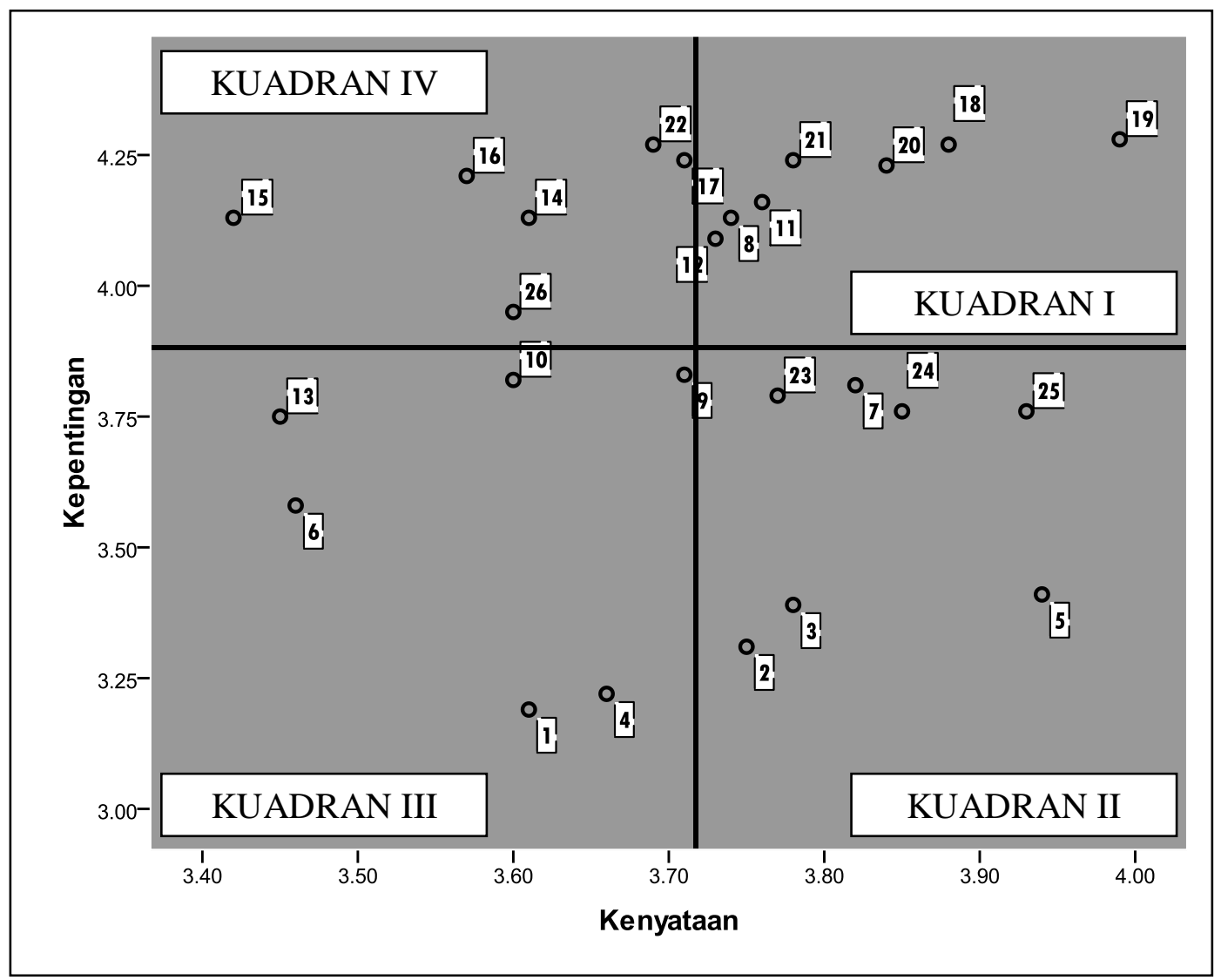

Sumber : Pengolahan Data

Gambar 3 Hasil Ploting Data Importance Performance Analysis

Pada gambar 3 tersebut dapat dilihat bahwa:

1. Pada kuadran pertama terdapat atribut keyakinan pelanggan terhadap kemampuan petugas, keterampilan pegawai dalam memberikan solusi, keterampilan pegawai dalam berkomunikasi dengan pelanggan, keakuratan informasi yang diberikan oleh petugas, kecepatan petugas dalam melayani pelanggan, dan kecepatan petugas dalam memberian solusi pada keluhan pelanggan.

Hal ini menggambarkan bahwa atribut-atribut tersebut memiliki nilai kepentingan dan kenyataan yang tinggi, sehingga tidak diperlukan adanya perbaikan.

2. Pada kuadran kedua terdapat atribut kelengkapan fasilitas pendukung ruang tunggu. (tempat sampah, tempat brosur, kotak saran, mesin antrian, dll), kenyamanan ruang tunggu, kerapian penampilan petugas customer service, kenyamanan counter pelayanan, kesediaan petugas mengucapkan salam sebelum dan sesudah melayani pelanggan, kesopanan petugas terhadap pelanggan, dan keramahan petugas dalam melayani pelanggan.

Hal ini menggambarkan bahwa atribut-atribut tersebut memiliki nilai kepentingan yang rendah dan nilai kenyataan yang tinggi, dengan demikian tidak diperlukan perbaikan pada atribut-atribut tersebut. 


\section{Angga Dharmawan Febriana Wurjaningrum}

3. Pada kuadran ketiga terdapat atribut ketersediaan fasilitas parkir yang memadai, kebersihan toilet di area ruang tunggu, jumlah counter pelayanan memadai, keyakinan pelanggan pada solusi yang diberikan petugas, keamanan area ruang tunggu, dan ketersediaan petugas tambahan pada saat terjadi antrian yang panjang.

Hal ini menggambarkan bahwa atribut-atribut tersebut memiiki nilai kepentingan dan kenyataan yang rendah. Dengan demikian perusahaan tidak dianjurkan untuk melakukan perbaikan karena atribut-atribut tersebut memiliki tingkat kepentingan yang rendah menurut pelanggan, tetapi perusahaan juga boleh melakukan perbaikan atribut-atribut tersebut dikarenakan rendahnya nilai kenyataan atribut-atribut tersebut.

4. Sedangkan pada kuadran keempat yang akan menjadi fokus dalam penelitian ini terdapat atribut kesiapan petugas dalam melayani pelanggan, kesiapan petugas tambahan pada saat terjadi antrian yang sangat panjang, kesiapan petugas merespon keluhan pelanggan, keakuratan pencatatan atau dokumentasi keluhan pelanggan, kesediaan petugas membantu pelanggan menanggapi keluhan, dan perhatian petugas terhadap keluhan yang disampaikan.

Hal tersebut menggambarkan bahwa atribut-atribut tersebut memiliki nilai harapan yang tinggi dan nilai kenyataan yang rendah. Dengan demikian penelitian ini akan berfokus lebih pada atribut-atribut tersebut.

\subsection{Analisis Quality Function Deployment (QFD)}

Setelah melakukan analisis gap menggunakan servqual dan analisis IPA, maka langkah selanjutnya adalah melakukan analisis QFD. Salah satu hal penting dalam QFD adalah House of Quality (HOQ). Tahap-tahap penyusunan $\mathrm{HOQ}$ adalah sebagai berikut :

1. Penyusunan Relationship Matrix

a. Penyusunan Customers Needs (WHATs)

Berdasarkan analisis IPA terdapat enam atribut yang digunakan sebagai Customers Needs pada house of quality, yaitu atribut kualitas pelayanan yang berada pada kuadran ke empat antara lain :

1. Kesiapan petugas dalam melayani pelanggan,

2. Kesiapan petugas tambahan pada saat terjadi antrian yang sangat panjang,

3. Kesiapan petugas merespon keluhan pelanggan,

4. Keakuratan pencatatan atau dokumentasi keluhan pelanggan,

5. Kesediaan petugas membantu pelanggan menanggapi keluhan, dan

6. Perhatian petugas terhadap keluhan yang disampaikan.

b. Penetapan Technical Requirement (HOWs)

Berdasarkan customers needs yang telah ditentukan, maka dapat ditetapkan beberapa respon teknik sebagai berikut :

1. Meningkatkan penerapan SOP 
2. Penambahan jumlah petugas.

3. Melakukan evaluasi petugas secara berkala.

4. Memberikan reward pada pegawai terbaik setiap bulan.

5. Maksimalisasi teknologi system informasi.

6. Menerapkan budaya $4 S$ (senyum, salam, sapa, sopan)

c. Penghubungan WHATs dan HOWs (Relationship Matrix)

Hasil Pemetaan hubungan antara WHATs dan HOWs adalah sebagai berikut:

Tabel 3 Matrix Hubungan WHATs dan HOWs

\begin{tabular}{|c|c|c|c|c|c|c|}
\hline \multirow{2}{*}{$\begin{array}{c}\text { Kebutuhan Pelanggan } \\
\text { (WHATs) }\end{array}$} & \multicolumn{7}{|c|}{$\begin{array}{c}\text { Respon Teknis } \\
\text { (HOWs) }\end{array}$} \\
\cline { 2 - 7 } & $\mathbf{1}$ & $\mathbf{2}$ & $\mathbf{3}$ & $\mathbf{4}$ & $\mathbf{5}$ & $\mathbf{6}$ \\
\hline $\mathbf{1}$ & 9 & 3 & & 3 & & \\
\hline $\mathbf{2}$ & 9 & 9 & & & & \\
\hline $\mathbf{3}$ & & & 9 & & & \\
\hline $\mathbf{4}$ & & & 9 & & 9 & \\
\hline $\mathbf{5}$ & & & 3 & 9 & & 9 \\
\hline $\mathbf{6}$ & & & & & & 9 \\
\hline
\end{tabular}

Sumber : Diskusi dengan Pihak Plasa TELKOM

d. Penghubungan antar HOWs (Technical Correlation)

Hasil pemetaan hubungan antar HOWs adalah sebagai berikut

Tabel 4 Matrix Hubungan antar HOWs

\begin{tabular}{|c|c|c|c|c|c|c|}
\hline $\begin{array}{c}\text { Respon Teknis } \\
\text { (HOWs) }\end{array}$ & $\mathbf{1}$ & $\mathbf{2}$ & $\mathbf{3}$ & $\mathbf{4}$ & $\mathbf{5}$ & $\mathbf{6}$ \\
\hline $\mathbf{1}$ & 9 & & & 9 & & 3 \\
\hline $\mathbf{2}$ & & 9 & & & & \\
\hline $\mathbf{3}$ & & & 9 & 9 & & \\
\hline $\mathbf{4}$ & 9 & & 9 & 9 & & \\
\hline $\mathbf{5}$ & & & & & 9 & \\
\hline $\mathbf{6}$ & 3 & & & & & 9 \\
\hline
\end{tabular}

Sumber : Diskusi dengan Pihak Plasa TELKOM

2. Penyusunan Planning Matrix

a. Penghitungan Nilai Customer Satisfaction Performance

Hasil perhitungan Customer Satisfaction Performance dapat dilihat pada tabel 5 berikut:

Tabel 5 Customer Satisfaction Performance

\begin{tabular}{|c|c|c|c|}
\hline \multirow{2}{*}{ Atribut } & \multicolumn{3}{|c|}{ Customer Satisfaction Performance } \\
\cline { 2 - 4 } & Kenyataan & Harapan & Gap \\
\hline 1 & 3,61 & 4,59 & $-0,98$ \\
\hline 2 & 3,45 & 4,60 & $-1,15$ \\
\hline 3 & 3,57 & 4,49 & $-0,92$ \\
\hline 4 & 3,71 & 4,50 & $-0,79$ \\
\hline 5 & 3,69 & 4,56 & $-0,87$ \\
\hline 6 & 3,60 & 4,66 & $-1,06$ \\
\hline
\end{tabular}

Sumber : Pengolahan Data 


\section{Angga Dharmawan Febriana Wurjaningrum}

b. Penghitungan Nilai Competitive Satisfaction Performance

Hasil perhitungan Competitive Satisfaction Performance dapat dilihat pada tabel 6 berikut:

Tabel 6 Customer Satisfaction Performance

\begin{tabular}{|c|c|c|c|}
\hline \multirow{2}{*}{ Atribut } & \multicolumn{3}{|c|}{$\begin{array}{c}\text { Competitive Satisfaction } \\
\text { Performance }\end{array}$} \\
\cline { 2 - 4 } & Kenyataan & Harapan & Gap \\
\hline 1 & 3,77 & 4,64 & $-0,87$ \\
\hline 2 & 3,48 & 4,64 & $-1,16$ \\
\hline 3 & 3,81 & 4,69 & $-0,88$ \\
\hline 4 & 3,60 & 4,71 & $-1,11$ \\
\hline 5 & 3,85 & 4,69 & $-0,84$ \\
\hline 6 & 3,90 & 4,75 & $-0,85$ \\
\hline
\end{tabular}

Sumber : Pengolahan Data

c. Penentuan Goal

Dalam penelitian ini, nilai goal diambil dari nilai harapan pelanggan Plasa TELKOM Dinoyo Surabaya. Hal ini dikarenakan nilai goal adalah suatu pencapaian yang dijadikan patokan keberhasilan dari upaya rancangan perbaikan kualitas layanan.

d. Penghitungan Nilai Improvement Ratio

Improvement ratio dapat dirumukan sebagai berikut:

$$
I R=\frac{\text { Goal }}{\bar{X} \text { Kenyataan }}
$$

Hasil perhitungan IR adalah sebagai berikut:

Tabel 7 Improvement Ratio

\begin{tabular}{|c|c|}
\hline Customers Needs & Improvement Ratio \\
\hline 1 & 1,27 \\
\hline 2 & 1,33 \\
\hline 3 & 1,26 \\
\hline 4 & 1,21 \\
\hline 5 & 1,24 \\
\hline 6 & 1,3 \\
\hline
\end{tabular}

Sumber : Pengolahan Data

e. Penentuan Sales Point

Pada penelitian ini, pihak manajemen Plasa TELKOM Dinoyo Surabaya menentukan nilai sales point sama untuk masing-masing customers needs yaitu 1,5 yang bermakna manajemen Plasa TELKOM Dinoyo Surabaya mengharapkan titik kepuasan kuat untuk masing-masing customers needs.

f. Penghitungan Nilai Raw Weight dan Normalized Raw Weight

Raw weight dan normalized raw weight dapat dirumuskan sebagai berikut:

$R W=$ Importance to Customer $x$ Improvement Ratio $x$ Sales Point

$$
N R W=\frac{\text { Raw Weight }}{\text { Total RawWeight }}
$$


Hasil perhitungan RW dan NRW dapat dilihat pada tabel 8 berikut:

Tabel 8 Raw Weight dan Normalized Raw Weight

\begin{tabular}{|c|c|c|c|}
\hline Customers Needs & RW & NWR & \% NRW \\
\hline 1 & 7,87 & 0,17 & $17 \%$ \\
\hline 2 & 8,24 & 0,18 & $18 \%$ \\
\hline 3 & 7,96 & 0,17 & $17 \%$ \\
\hline 4 & 7,70 & 0,17 & $17 \%$ \\
\hline 5 & 7,05 & 0,15 & $15 \%$ \\
\hline 6 & 7,71 & 0,17 & $17 \%$ \\
\hline Total & 46,53 & 1 & $100 \%$ \\
\hline
\end{tabular}

Sumber : Pengolahan Data

3. Penyusunan Technical Matrix

a. Penghitungan Nilai Contribution dan Normalized Contribution

Nilai contribution dan normalized contribution dapat dirumuskan sebagai berikut :

Contribution $=\sum($ Normalized Raw Weight $x$ Numeric Value $)$

Normalized Contribution $=\frac{\text { Contribution }}{\text { Total Contribution }}$

Hasil perhitungan contribution dan normalized contribution dapat dilihat pada tabel 9 berikut :

Tabel 9 Contribution dan Normalized Contribution Respon Teknis

\begin{tabular}{|c|c|c|c|c|}
\hline Technical Response & C & NC & \%NC & Prior \\
\hline 1 & 3,06 & 0,201 & $20,1 \%$ & 2 \\
\hline 2 & 2,16 & 0,142 & $14,2 \%$ & 4 \\
\hline 3 & 3,57 & 0,234 & $23,4 \%$ & 1 \\
\hline 4 & 2,04 & 0,134 & $13,4 \%$ & 5 \\
\hline 5 & 1,35 & 0,089 & $8,9 \%$ & 6 \\
\hline 6 & 3,06 & 0,201 & $20,1 \%$ & 3 \\
\hline Total & 15,24 & 1 & $100 \%$ & \\
\hline
\end{tabular}

Sumber : Pengolahan Data

b. Penghitungan Nilai Own Performance

Own performance dapat dirumuskan sebagai berikut :

SCustomer Satisfaction Performance x Nilai Numerik

¿Nilai Numerik

Hasil perhitungan own performance dapat dilihat pada tabel 10 berikut:

Tabel 10 Own Peformance

\begin{tabular}{|c|c|}
\hline Technical Response & $\begin{array}{c}\text { Own } \\
\text { Performance }\end{array}$ \\
\hline 1 & 3,53 \\
\hline 2 & 3,49 \\
\hline 3 & 3,65 \\
\hline 4 & 3,67 \\
\hline 5 & 3,71 \\
\hline 6 & 3,65 \\
\hline
\end{tabular}

Sumber : Pengolahan Data 


\section{Angga Dharmawan Febriana Wurjaningrum}

c. Penghitungan Nilai Competitive Performance

Rumus menghitung competitive performance sama dengan rumus menghitung own performance, hanya saja customers satisfaction performance diganti dengan competitive satisfactionperformance. Hasil perhitungan competititve performance dapat dilihat pada tabel 11 berikut:

Tabel 11 Competitive Peformance

\begin{tabular}{|c|c|}
\hline Technical Response & $\begin{array}{c}\text { Competitive } \\
\text { Performance }\end{array}$ \\
\hline 1 & 3,63 \\
\hline 2 & 3,55 \\
\hline 3 & 3,73 \\
\hline 4 & 3,83 \\
\hline 5 & 3,94 \\
\hline 6 & 3,88 \\
\hline
\end{tabular}

Sumber : Pengolahan Data

d. Penentuan Target

Penentuan target dilakukan berdasarkan nilai own performance dan competitive performance, serta pertimbangandari nilai gap pada customer satisfaction performance. Nilai target Plasa TELKOM DInoyo Surabaya dapat dilihat pada tabel 12 berikut:

Tabel 12 Nilai Target

\begin{tabular}{|c|c|c|c|}
\hline Technical Response & $\begin{array}{c}\text { Own } \\
\text { Performance }\end{array}$ & $\begin{array}{c}\text { Competitive } \\
\text { Performance }\end{array}$ & Target \\
\hline 1 & 3,53 & 3,63 & 4 \\
\hline 2 & 3,49 & 3,55 & 4 \\
\hline 3 & 3,65 & 3,73 & 3 \\
\hline 4 & 3,67 & 3,83 & 3 \\
\hline 5 & 3,71 & 3,94 & 4 \\
\hline 6 & 3,65 & 3,88 & 3 \\
\hline
\end{tabular}

Sumber : Pengolahan Data

4. Hasil House of Quality

Berikut merupakan hasil penyusunan House of Quality Plasa TELKOM Dinoyo Surabaya yang dapat dilihat pada gambar 4 


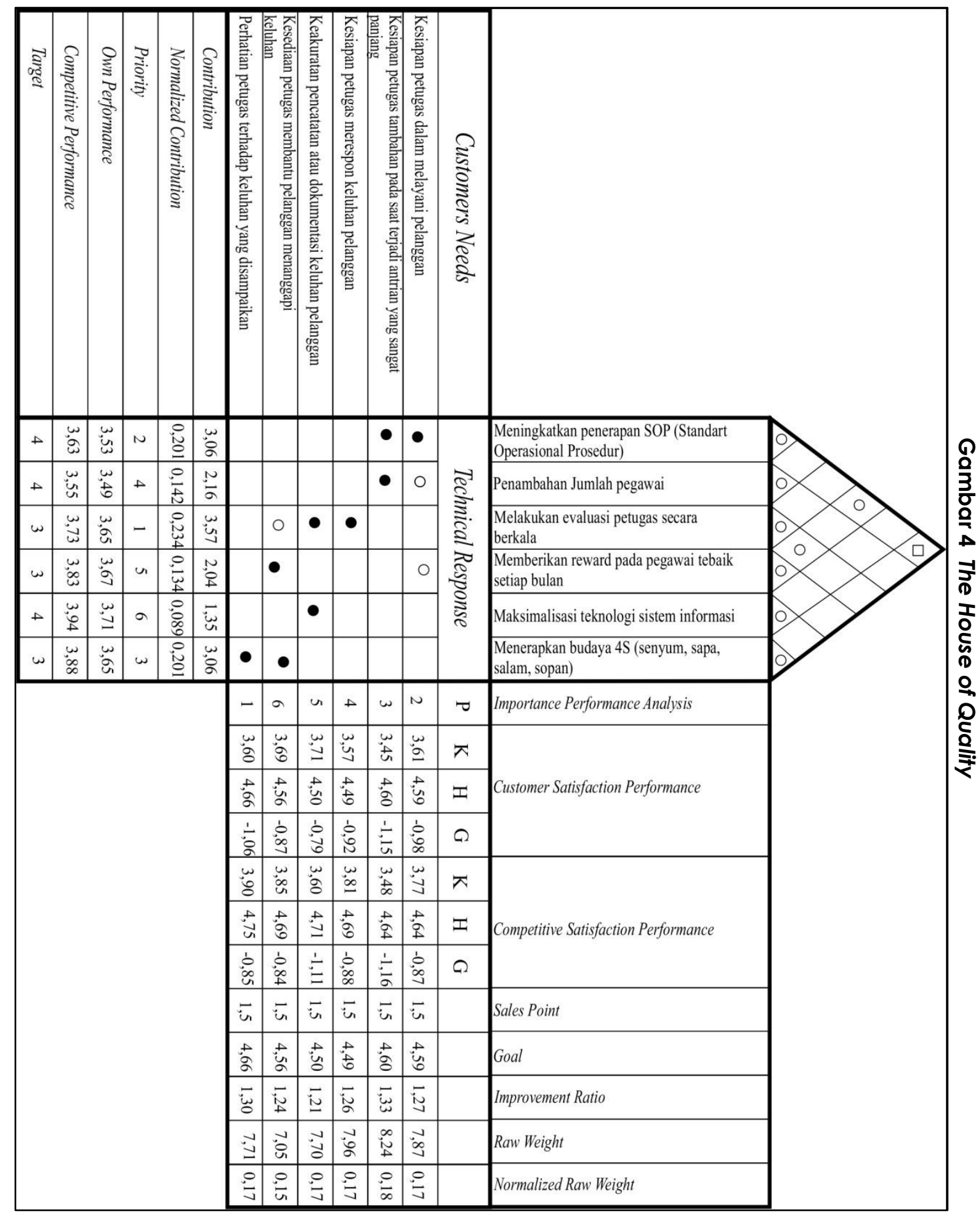




\section{Angga Dharmawan \\ Febriana Wurjaningrum}

\section{Simpulan}

Berdasarkan analisis dan interpretasi dari pengolahan data yang telah dilakukan, makadapat ditarik kesimpulan sebagai berikut:

a. Pelayanan Plasa TELKOM Dinoyo Surabaya masih memerlukan perbaikan, karena berdasarkan analisis gap servqual setiap atribut pelayanan memiliki nilai gap negatif.

b. Terdapat enam atribut pelayanan yang diprioritakan untuk dilakukan perbaikan berdasarkan hasil analisis IPA, antara lain adalah kesiapan petugas dalam melayani pelanggan, kesiapan petugas tambahan pada saat terjadi antrian yang sangat panjang, kesiapan petugas merespon keluhan pelanggan, keakuratan pencatatan atau dokumentasi keluhan pelanggan, kesediaan petugas membantu pelanggan menanggapi keluhan, dan perhatian petugas terhadap keluhan yang disampaikan.

c. Pada hasil QFD dapat dilihat bahwa untuk melakukan peningkatan kualitas layanan Plasa TELKOM seharusnya lebih menekankan pada evaluasi petugas front liner secara berkala, meningkat penerapan SOP, dan menerapkan budaya 4S. Prioritas selanjutnya adalah melakukan penambahan petugas front liner, pemberian reward pada pegawai terbak setiap bulan, serta memaksimalkan teknologi system informasi yang dsediakan untuk melayani pelanggan.

\section{Daftar Referensi}

Brandt, D. R. (2000). An "Outside-In" Approiach to Determining Customer-Driven Priorities for Improvement and Innovation. White Paper Serie .

Dharmawan, Angga dan Febriana Wurjaningrum, 2015. Rancangan Perbaikan Kualitas Pelayan Jasa Dengan Metode Servqual Importance Performance Analysis dan Quality Function Deployment Pada Plasa Telkom Cab. Dinoyo Surabaya, Program Studi S1 Manajemen Unair, 174.

Gaspersz, V. (1997). Manajemen Kualitas: Penerapan Konsep VINCENT dalam MANAJEMEN BISNIS TOTAL. Jakarta: Gramedia Pustaka Utama.

Kotler, P., \& Armstrong, G. (2001). Principles of Marketing. New Jersey: Prentice Hall.

Kotler, P., Hayes, T., \& Bloom, P. N. (2002). Marketing Professional Services. New Jersey: Prentice Hall Press.

Martilla, J., \& James, J. (1977). Importance-Performance Analysis. The Journal of Marketing, 77-79.

Martinez, C. L. (2003). Evaluation Report: Tools Cluster Networking Meeting. Arizona: Center Point Institute, Inc. 